\title{
Evaluation of Antipyretic and Analgesic Effects of Aqueous Extract of Leaves of Vernonia Amygdalina Del. (Asteraceae)
}

\section{Elion Itou RDG1,2*, Etou Ossibi AW1,2, Nsonde Ntandou GF 1,2, Morabandza CJ1,3, Mayela Nkouka SHJ, Bokia CB ${ }^{1}$ and Abena AA ${ }^{1}$}

${ }^{1}$ Laboratoire de Biochimie et de Pharmacologie, Faculté des Sciences de la Santé, Université Marien Ngouabi, BP 69, Brazzaville, Congo

2Laboratoire de physiologie animale, Faculté des Sciences et Techniques, Université Marien Ngouabi, BP 69, Brazzaville, Congo

32Département des Sciences Naturelles, École Normale Supérieure, Université Marien Ngouabi Congo, BP 69, Brazzaville, Congo

*Corresponding author: Elion Itou Romaric De Garde, Maître assistant-CAMES, Faculté des Sciences et Techniques, Université Marien Ngouabi, Brazzaville-Congo, Tel: 00242066607836; E-mail: romaricelion@gmail.com

\section{Abstract}

Objective: This study aims to evaluate the antipyretic and analgesic effects of leaves of $V$. amygdalina collected in Brazzaville-Congo.

Method: The antipyretic effect was induced using brewer's yeast induced pyrexia. The results obtained show that paracetamol and the aqueous extract of $V$. amygdalina at the doses used (400 and $800 \mathrm{mg} / \mathrm{kg}$ ) increased significantly (p < 0.05; $\mathrm{p}<0.01$ and $\mathrm{p}<0.001$ ) pyrexia induced by brewer's yeast from the second hour to the fifth hour of observation. Analgesic effect was evaluated by using the acetic acid-induced writhing, the pressure induced by the analgesymeter as well as the pain induced by formaldehyde. The results obtained show that the aqueous extract at the doses used (400 and $800 \mathrm{mg} / \mathrm{kg}$ ) significantly ( $<$ 0.05; $\mathrm{p}<0.001$ ) reduces the number of abdominal writhing induced by acetic acid, significantly increased the latency time of the paw of the animal at the pressure induced by the analgesic meter $(\mathrm{p}<0.05$ and $\mathrm{p}<0.01$ ) and also significantly decreased the number of licking or biting of the paw compared to the control ( $\mathrm{p}<$ 0.001).

Conclusion: This result suggests that the aqueous extract of leaves of V.amygdalina at doses used (400 and $800 \mathrm{mg} / \mathrm{kg}$ ) has an antipyretic and an antalgic effects.

Keywords: Antipyretic Effect; Analgesic Effect; Vernonia Amygdalina; Immunological; Infusions 


\section{Introduction}

Herbal medicine has developed over centuries in different cultures. Written traces are proof that man has always been interested in plants as a source of food, or a means of curing his diseases [1]. In West Africa, as in the rest of the continent, more than $80 \%$ of the population uses traditional medicine and medicinal plants for their primary health care [2]. Plants contain a molecular diversity of secondary metabolites [1,3]. This molecular diversity is of interest to scientific research for the discovery of new active ingredients or the development of improved traditional medicines to combat pathologies including fever and pain. Building on this reality, WHO's strategy since 2002 has been to commission the governments of member states to: "integrate the relevant aspects of traditional medicine into national health systems" [4]. Indeed, pain and fever can be treated in the Congo by the use of medicinal plants $[5,6]$. V.amydalina is a medicinal plant known to have several properties as justified by its wide use in different traditional African medicines. Boiled leaves are used for the treatment of intestinal worms, fever, malaria, diarrhea, dysentery, hepatitis, cough and fertility. They are also used as a laxative, remedy for scabies, wounds, headaches and stomach upset. Root extracts are used for the treatment of malaria, gastrointestinal diseases and intestinal worms. In Congo, it is commonly used to treat cutaneous lesions [6]. In Nigeria, leaves are applied to wounds to replace iodine tincture. In Zimbabwe, root infusion is used to treat sexually transmitted diseases. Bark infusions are also taken to treat fever and diarrhea, and dried flowers are used against stomach disorders [7]. Previous pharmacological studies have shown that $V$. amygdalina has properties such as antimalarial [8]; antioxidative [9,10]; Immunological [11]; Antidiabetic [12]; antiinflammatory and antinociceptive $[10,13]$. In this study, we aimed investigated antipyretic and analgesic effects of leaves of V.amygdalina (Asteraceae) collected in Brazzaville-Congo.

\section{Plant Material}

Dry and sprayed leaves of $V$. amygdalina (Asteraceae) were used. These leaves were collected in Brazzaville. Botanical identification of the plant material was done by Mousamboté, botanist systematist of Higher Normal School of Agronomy and Forestry (HNSAF) and confirmed at the Herbarium of the National Institute for Research in Exact and Natural Sciences (NIRENS) witch a collected sample was compared to a reference sample (No. 8331 of 13.10 1950). After that, the drying of collected leaves was done at the Laboratory of the Faculty of Science and Technology for 14 days at $27 \pm 1^{\circ} \mathrm{C}$. After that, plant material were dried and pulverized with a mortar. The powder obtained was used to prepare the aqueous extract. $250 \mathrm{~g}$ of powder from the dry leaves were mixed in $2500 \mathrm{ml}$ of distilled water in a balloon heater. The whole was boiled for 15 minutes. After cooling and filtration, the filtrate obtained was evaporated in a water bath. Using a spatula, the filtrate was mixed continuously until complete evaporation of water. The aqueous extract obtained was preserved to evaluate the antipyretic and analgesic effects.

\section{Animals}

Albino rats (150-200 g) and albino mice (25-30 g) of either sex obtained from the Faculty of Science and Technical of Marien NGOUABI-University were used. They were fed with a standard feed and water ad libitum. They were acclimatized during one week before experimentation and were housed under standard conditions (12 hours light and 12 hours dark) and at the temperature of $27 \pm 1{ }^{\circ} \mathrm{C}$. The rules of ethics published by the International Association for the Study of Pain [14] have been considered.

\section{Methods}

\section{Brewer's Yeast Pyrexia Test}

The method described by Abdur et al, (2014) was used [15]. The animals were divided into groups of 5 rats each and their normal temperature was recorded using digital thermometer. Pyrexia was induced by injection of 10 $\mathrm{mL} / \mathrm{kg}$ s.c. of $20 \%$ suspension of Brewer's yeast (Saccharomyces cerevisiae). After $24 \mathrm{~h}$ rectal temperature was recorded. All the animals which did not present an increase in their rectal temperature of $0.5{ }^{\circ} \mathrm{C} 24^{\text {th }}$ hours after the local injection of Brewer's yeast were isolated [16]. After that aqueous extract of V.amygdalina (400 and $800 \mathrm{mg} / \mathrm{kg}$ ), paracetamol (standard drug, $100 \mathrm{mg} / \mathrm{kg}$ ) and physiological solution (control group, $0.5 \mathrm{~mL} / 100 \mathrm{~g}$ ) were administered orally to groups. Rectal temperature was recorded periodically at 1, 2, 3, 4 and 5 hours after drugs administration. Antipyretic activity was defined as the ability of test drugs to reverse the induced pyrexia [16].

\section{Acetic Acid-Induced Pain In Mice}

The pain was induced in the mice by using $0.6 \%$ acetic acid solution [17]. The animals were divided into groups of 6 mice each. Aqueous extract of V.amygdalina (400 and $800 \mathrm{mg} / \mathrm{kg}$ ), paracetamol (standard drug, $50 \mathrm{mg} / \mathrm{kg}$ ) and distilled water (control group, $0.5 \mathrm{~mL} / 100 \mathrm{~g}$ ) were administered orally to groups, one hour prior to the local injection of acetic acid (10 ml/kg, IP). 5 minutes after 


\section{Bioequivalence \& Bioavailability International Journal}

acetic acid injection, the number of writhing made by each mouse was recorded during 20 minutes [18]. A substance that has an analgesic effect will reduce the number of abdominal cramps compared to the control group. The analgesic effect was given by the inhibition (I) of the abdominal writhing.

\section{Analgesymeter Induced Pain Experiment}

Method described by Elion Itou et al. (2017) was used [18]. The animals were divided into groups of 6 rats each. Aqueous extract of V.amygdalina (400 and $800 \mathrm{mg} / \mathrm{kg}$ ), paracetamol (standard drug, $50 \mathrm{mg} / \mathrm{kg}$ ) and distilled water (control group, $0.5 \mathrm{~mL} / 100 \mathrm{~g}$ ) were administered orally to groups. One (1) hour after oral administration of the tested products, nociceptive thresholds were determined by using the analgesymeter (Cat. No. 37215 Ugo Basile, Italy). A constantly increasing pressure was applied on the right hand paw until the rats withdraw the paw. The sensitivity threshold to pain was determined and the reaction time calculated [18].

\section{Formaldehyde Induced Hind Pain}

The pain was induced by using $2.5 \%$ formaldehyde solution $[18,19]$. The animals were divided into groups of 5 rat each. Different doses of aqueous extract of V.amygdalina (400 and $800 \mathrm{mg} / \mathrm{kg}$ ), Tramadol (standard drug, $10 \mathrm{mg} / \mathrm{kg}$ ) and distilled water (control group, 0.5 $\mathrm{mL} / 100 \mathrm{~g}$ ) were administered orally to groups, one hour prior to the local injection of formaldehyde subcutaneous tissue of the plantar surface of the right paw. Animals were placed in various cages to observe the noxious effects. The frequency (Number of licking or biting paw/10 min) that the animal licks or bites its paw was monitored over 0-10 min for neurogenic pain response and 10-30 min for inflammatory pain response. The analgesic effect was given by the inhibition of the pain [18]. A central analgesic would inhibit the two phases equally, but a peripheral analgesic would only inhibit the second phase [20].

\section{Result}

\section{Antipyretic Effect of Aqueous Extract of V.Amygdalina}

The results are shown in Table 1 . They show that all the experimental animals had a hyperthermia greater than $0.5^{\circ} \mathrm{C}$ compared to their normal rectal temperature 24 hours after subcutaneous administration of the brewer's yeast. The aqueous extract of V.amygdalina leaves at the doses used ( 400 and $800 \mathrm{mg} / \mathrm{kg}$ ) and the paracetamol used as the reference molecule did not significantly decrease the rectal temperature 1 hour after induction of pyrexia ( $p>0.05)$. However, from 2 hours to 5 hours, the aqueous extract of V.amygdalina at the doses used (400 and $800 \mathrm{mg} / \mathrm{kg}$ ) as well as paracetamol attenuate significantly $(\mathrm{p}<0.05 ; \mathrm{p}<0.01$ and $\mathrm{p}<0.001)$ pyrexia induced in all rats by the injection of Brewer's yeast (Saccharomyces cerevisiae) with a maximum at 2 and 3 hours for aqueous extract respectively at the doses of 800 and $300 \mathrm{mg} / \mathrm{kg}$. In addition, the maximum temperature decrease is obtained at $3 \mathrm{~h}$ with paracetamol $(100 \mathrm{mg} / \mathrm{kg})$ used as a reference molecule.

\section{Effect of the Aqueous Extract of V.Amygdalina on Pain Induced by Acetic Acid}

The administration of acetic acid to the experimental animals caused abdominal writhes (Table 2). Paracetamol and aqueous extract at the doses used significantly decreased abdominal writhes $(\mathrm{P}<0.001)$ compared to the control group (distilled water). The number of abdominal writhes developed by the experimental animals is $109.33 \pm 0.39$ (control group); of $99.66 \pm 0.20$ (paracetamol, standard drug); of $72.82 \pm 3.94$ for the aqueous extract at the dose of $400 \mathrm{mg} / \mathrm{kg}$ and finally $56.66 \pm 4.10$ for aqueous extract at the dose of $800 \mathrm{mg} / \mathrm{kg}$. The strongest inhibition is observed with the aqueous extract at $800 \mathrm{mg} / \mathrm{kg}(48.17 \%)$ compared to the aqueous extract at $400 \mathrm{mg} / \mathrm{kg}(33.39 \%)$ and paracetamol $(8.84$ $\%)$.

\begin{tabular}{|c|c|c|}
\hline Treatment & Number of abdominal writhes & Inhibition \% \\
\hline Control group $(0.5 \mathrm{~mL} / 100 \mathrm{~g})+$ Ac. Acet $(10 \mathrm{~mL} / \mathrm{kg}, \mathrm{IP})$ & $109.33 \pm 0.39$ & $/$ \\
\hline Para. $(50 \mathrm{mg} / \mathrm{kg})+$ Ac. Acet $(10 \mathrm{~mL} / \mathrm{kg}, \mathrm{IP})$ & $99.66 \pm 0.20^{* * *}$ & 8.84 \\
\hline Ver. $a(400 \mathrm{mg} / \mathrm{kg})+$ Ac. Acet $(10 \mathrm{~mL} / \mathrm{kg}, \mathrm{IP})$ & $72.82 \pm 3.94^{* * *}$ & 33.39 \\
\hline Ver.a $(800 \mathrm{mg} / \mathrm{kg})+$ Ac. Acet $(10 \mathrm{~mL} / \mathrm{kg}, \mathrm{IP})$ & $56.66 \pm 4.10^{* * *}$ & 48.17 \\
\hline
\end{tabular}

Each value represents the mean \pm ESM of abdominal writhes. ${ }^{* * *} \mathrm{P}<0.001$ significant different (Student $\mathrm{t}$-test) versus control group. Ac. Acet= acetic acid; Para= paracetamol; Ver.a= Vernonia amygdalina

Table 1: Effect of aqueous extract of V.amygdalina in abdominal writhes induced by acetic acid $0.6 \%$ in mice. 


\section{Bioequivalence \& Bioavailability International Journal}

\section{Effect on the Pain Induced by the Analgesy Meter}

The pressure induced by the analgesymeter caused pains in the legs of the experimental animals (Figure 1). Paracetamol and the aqueous extract at the doses used (400 and $800 \mathrm{mg} / \mathrm{kg}$ ) significantly increase the reaction time ( $\mathrm{P}<0.001$ ) following the pain induced by the apparatus compared to the control group (distilled water). This time is $2.76 \pm 0.13 \mathrm{Sec}$ for the control group; $4.13 \pm 0.20 \mathrm{Sec}$ for paracetamol; 7.32 $\pm 0.37 \mathrm{Sec}$ for the aqueous extract at $400 \mathrm{mg} / \mathrm{kg}$ and $8.02 \pm 0.20 \mathrm{Sec}$ for the aqueous extract at $800 \mathrm{mg} / \mathrm{kg}$.

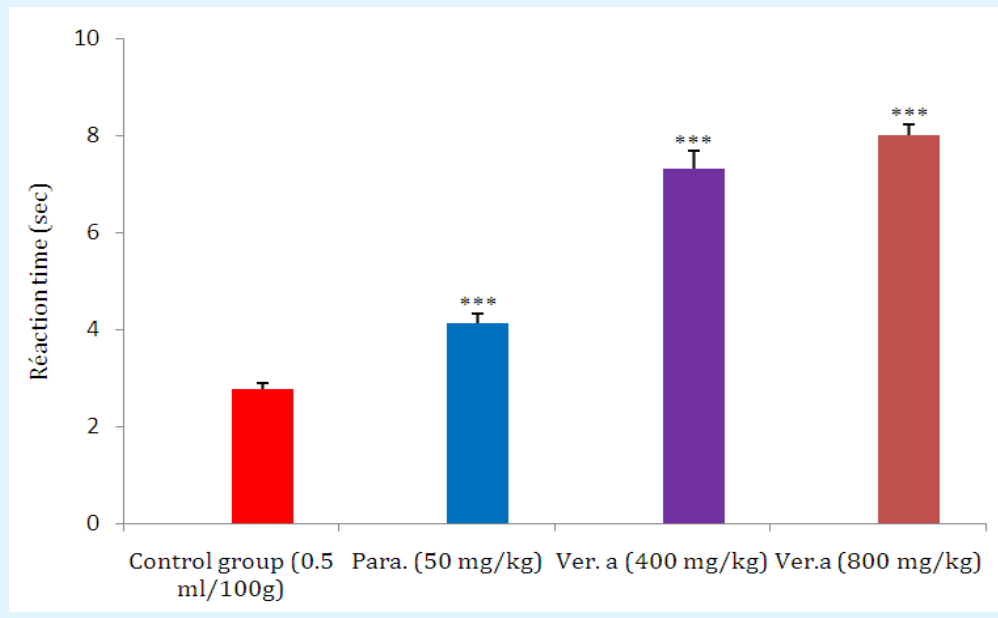

Figure 1: Effect of aqueous extract of V. amygdalina in animals reaction time (Sec): ${ }^{* * *} \mathrm{P}<0.001$ significant different (Student $\mathrm{t}$-test) versus control group. Para= paracetamol; Ver.a= Vernonia amygdalina.

\section{Effect of the Aqueous Extract of V.Amygdalina on Pain Induced by Formaldehyde}

Subcutaneous tissue of the plantar surface administration of the formaldehyde solution caused neurogenic pain response and inflammatory pain response in experimental animals (Table 3). During the neurogenic pain response and the inflammatory pain response, the tramadol $(10 \mathrm{ml} / \mathrm{kg})$ and aqueous extract at the doses used ( 400 and $800 \mathrm{mg} / \mathrm{kg}$ ) significantly reduced the frequency of licking or biting of the paw $(p<0.001)$. During the neurogenic pain response, the frequencies and inhibitions are $31.48 \pm 3.74$ for the control group; $8.2 \pm 0.48$ (73.88 \% of inhibition) for tramadol; $10.8 \pm 0.37$ (63.85\% of inhibition) for the extract aqueous $400 \mathrm{mg} / \mathrm{kg}$ and $7.33 \pm 1.94$ (76.65 \% of inhibition) for the aqueous extract $800 \mathrm{mg} / \mathrm{kg}$. During the inflammatory pain response, frequencies and inhibitions are $66.40 \pm 1.93$ for the control group; of $11.40 \pm 1.69$ ( $82.83 \%$ of inhibition) for tramadol; $24.00 \pm 1.38$ (63.85\% of inhibition) for aqueous extract $400 \mathrm{mg} / \mathrm{kg}$ and $17.8 \pm 1.94$ (73.19\% of inhibition) the aqueous extract $800 \mathrm{mg} / \mathrm{kg}$.

\begin{tabular}{|c|c|c|c|c|c|c|c|c|}
\hline \multirow{2}{*}{\multicolumn{2}{|c|}{ Treatment Doses }} & \multirow[b]{2}{*}{$\mathbf{T}^{\circ}$ normal } & \multicolumn{6}{|c|}{ Temperature $\left(\mathrm{T}^{\circ}\right)$ after pyrexia induced } \\
\hline & & & Oh & \multirow{2}{*}{\begin{tabular}{|c|}
$\mathbf{1 h}$ \\
$7.82 \pm 0.23$ \\
\end{tabular}} & \multirow{2}{*}{\begin{tabular}{|c|}
$\mathbf{2 h}$ \\
$37.688 \pm 0.07$ \\
\end{tabular}} & \multirow{2}{*}{\begin{tabular}{|c|}
$\mathbf{3 h}$ \\
$37.512 \pm 0.58$ \\
\end{tabular}} & \multirow{2}{*}{\begin{tabular}{|c|}
$\mathbf{4 h}$ \\
$37.428 \pm 0.50$ \\
\end{tabular}} & \multirow{2}{*}{$\begin{array}{c}\mathbf{5 h} \\
37.44 \pm 0.22\end{array}$} \\
\hline $\begin{array}{l}\text { Control } \\
\text { group }\end{array}$ & $(0.5 \mathrm{~mL} / 100 \mathrm{~g}$ & $36.58 \pm 0.28$ & $37.58 \pm 0.17$ & & & & & \\
\hline para. & $(100 \mathrm{mg} / \mathrm{kg})$ & $36.10 \pm 0.21$ & $37.12 \pm 0.20$ & $37.06 \pm 0.45 \mathrm{~ns}$ & $36.08 \pm 0.35^{* *}$ & $35.84 \pm 0.30 * * *$ & $35.68 \pm 0.50 * * *$ & $35.68 \pm 0.26^{* *}$ \\
\hline \multirow[t]{2}{*}{ V.amyg } & $(400 \mathrm{mg} / \mathrm{kg})$ & $35.92 \pm 0.25$ & $37.1 \pm 0.27$ & $36.94 \pm 0.23 \mathrm{~ns}$ & $36.55 \pm 0.14^{*}$ & $36.352 \pm 0.20^{* * *}$ & $36.16 \pm 0.52^{* * *}$ & $36.14 \pm 0.16^{* *}$ \\
\hline & $(800 \mathrm{mg} / \mathrm{kg})$ & $35.96 \pm 0.06$ & $36.98 \pm 0.22$ & $36.66 \pm 0.13 \mathrm{~ns}$ & $36.44 \pm 0.12^{* * *}$ & $36.26 \pm 0.3^{* * *}$ & $36.16 \pm 0.50 * * *$ & $36.04 \pm 0.27^{* * *}$ \\
\hline
\end{tabular}

Each value represents the mean \pm ESM of temperature. ${ }^{*} \mathrm{p}<0.05$, ${ }^{* *} \mathrm{p}<0.01$ and ${ }^{* * *} \mathrm{P}<0.001$ significant different (Student $\mathrm{t}$ test) versus control group. ns $=$ no significant value $p>0.05$; Ver.a $=$ Vernonia amygdalina

Table 2: Effect of aqueous extract of V.amygdalina in pyrexia induced by the injection of Brewer's yeast (Saccharomyces cerevisiae). 


\section{Bioequivalence \& Bioavailability International Journal}

\begin{tabular}{|c|c|c|c|c|c|}
\hline \multicolumn{2}{|c|}{} & \multicolumn{2}{c|}{ Neurogenic pain response (0-10 min) } & \multicolumn{2}{c|}{ Inflammatory pain response (10-30 min) } \\
\hline \multirow{2}{*}{ Treatment } & Doses & $\begin{array}{c}\text { Frequency (Hz) of legs } \\
\text { lickind and of biting }\end{array}$ & Inhibition \% & $\begin{array}{c}\text { Frequency (Hz) of legs } \\
\text { lickind and of biting }\end{array}$ & Inhibition \% \\
\hline Control group & $(0.5 \mathrm{~mL} / 100 \mathrm{~g})$ & $31.40 \pm 3.74$ & $/$ & $66.40 \pm 1.93$ & $/$ \\
\hline Tramadol & $(10 \mathrm{mg} / \mathrm{kg})$ & $8.20 \pm 0.48^{* * *}$ & 73.88 & $11.4 \pm 1.69^{* * *}$ & 82.83 \\
\hline V.amyg & $(400 \mathrm{mg} / \mathrm{kg})$ & $10.80 \pm 0.37^{* * *}$ & 65.60 & $24,00 \pm 1.38^{* * *}$ & 63.85 \\
\cline { 2 - 6 } & $(800 \mathrm{mg} / \mathrm{kg})$ & $7.33 \pm 1.94^{* * *}$ & 76.65 & $17.80 \pm 1.94^{* * *}$ & 73.19 \\
\hline
\end{tabular}

Each value represents the mean $\pm \mathrm{ESM}$ of frequency. ${ }^{* * *} \mathrm{P}<0.001$ significant different (Student $\mathrm{t}$-test) versus control group. Ver. amyg= Vernonia amygdalina

Table 3: Effect of aqueous extract of V.amygdalina in pain induced by formaldehyde $2.5 \%$.

\section{Discussion}

Pyrexia was induced by subcutaneous administration of Brewer's yeast (Saccharomyces cerevisiae). Brewer's yeast induces hyperthermia by increasing prostaglandin synthesis [21]. The hyperthermia induced by the injection of Brewer's yeast is linked to the release of cytokines (TNF $\alpha$, IL1 $\beta$, and IL6) which have reached the blood vessels stimulate the biosynthesis of prostaglandins (PGE2) around the hypothalamic thermoregulatory center $[22,23]$. Aqueous extract of V.amygdalina attenuate significantly $(\mathrm{p}<0.05 ; \mathrm{p}<0.01$ and $\mathrm{p}<0.001)$ pyrexia induced in all rats by the injection of Brewer's yeast. This result suggests an antipyretic effect of aqueous extract of V.amydalina which could pass by the interference with one of mechanism of Brewer's yeast induced pyrexia.

In this study, we used three methods to evaluate the analgesic effect of the aqueous extract of $V$. amygdalina leaves. Acetic acid and the analgesymeter test induces peripheral pain, the formaldehyde test induces central and peripheral pain [24]. Intraperitoneally administration of acetic acid induced abdominal writhes in mice. Acetic acid is a sensory irritant that induces peripheral pain $[17,25]$. This induction of pain by acetic acid causes an increase in the peritoneal fluid of prostaglandins (PGE2 and PGF2 $\alpha$ ) as well as lipooxygenase products involved partly in the peritoneal receptors and cause peripheral inflammatory pain response by inducing capillary permeability [26-28]. In this study, aqueous extract at the doses used significantly decreased abdominal writhing ( $P$ $<0.001$ ) compared to the control group (distilled water). This result suggests an analgesic effect of aqueous extract of V.amygdalina. The effect of the aqueous extract was evaluated on peripheral-type pain with the Analgesimeter. In fact, tissue trauma caused by mechanical pressure causes local swelling of the traumatized tissues responsible for the release of bradykinin, serotonin, potassium and hydrogen ions [29]. These substances are typically algogenic substances that activate nociceptors [30,31]. The production of lactic acid is also responsible for the pain encountered during ischemia or muscle exercises, histamine, substance $P$, prostaglandins [29]. Prostaglandins and probably leukotrienes are not very algogenic but play a key role since they sensitize receptors to the action of other substances [32,33]. The fact that the aqueous extract $(400$ and $800 \mathrm{mg} / \mathrm{kg}$ ) opposes this mechanical type of pain suggests that it interferes or inhibits the release of these algogenic mediators. These two methods are not specific; that's why the formaldehyde test was used. The formaldehyde test is a very important model used to highlight not only the analgesic effect but also to clarify the mechanisms of analgesic action. Subplantar administration of $2.5 \%$ formaldehyde in rats induces neurogenic response pain and inflammatory response pain [34]. The neurogenic pain response is a direct result of the stimulation of nociceptors in rats. The paw and reflects the central pain caused by the release of substance $\mathrm{P}$ at the central level. The inflammatory pain response is due to the release of histamine, serotonin, bradykinin and prostaglandins [35], which are the precursors of peripheral pain. Aqueous extract at the doses used (400 and $800 \mathrm{mg} / \mathrm{kg}$ ) significantly reduced the frequency of licking or biting of the paw $(\mathrm{p}<0.001)$ during the neurogenic pain response and inflammatory pain response. This result suggests that aqueous extract could have a peripheral and central analgesic effect.

\section{Conclusion}

V.amydalina is a Congolese medicinal plant known to have several properties. It appears from this study that its aqueous extract at the doses used has an antipyretic and analgesic effect what could justify its traditional use in the treatment of fever and pain.

\section{Conflict of Interests}

The authors declare that they have no conflict of interest. 


\section{Bioequivalence \& Bioavailability International Journal}

\section{References}

1. Anton MWR (2003) Plantes therapeutiques.Tradition,pratique officinale, science et therapeutiques. $2^{\text {nd }}$ (Edn.), Paris - Cachan 1: 692.

2. OMS (1978) Les Sp - rapport de la conférence internationale sur les SSP Alma- ata. Geneve: OMS ed Geneve, pp: 88.

3. Gurib-Fakim A (2008) Toutes les plantes qui soignent : Plantes d'hier, médicaments d'aujourd'hui. Italie: Michelle Lafon.

4. OMS (2003) Stratégie de l'OMS pour la Médecine traditionnelle pour 2002-2005. Document WHO/EDM/TRM / 2002

5. Bouquet A (1969) Féticheurs et médecines traditionnelles du Congo (Brazzaville). In Office de la Recherche Scientifique et Technique Outre-Mer (ORSTOM). Paris, pp: 283.

6. Adjanohoum E, Ahyi AM, Aké Assi L, Baniakina J, Chibon P, et al. (1988) Contribution aux études ethnobotaniques et floristiques en République Populaire du Congo. In Médecine traditionnelle et pharmacopée. Paris: Edition ACCT 1: 605.

7. Web: «Vernonia amygdalina (PROTA)» [archive], on uses.plantnet-project.org

8. Iwalokun BA (2008) Enhanced antimalarial effects of chloroquine by aqueous Vernonia amygdalina leaf extract in mice infected with chloroquine resistant and sensitive Plasmodium berghei strains. Afr Health Sci 8(1): 25-35.

9. Ebenezer OF, Owoeye O (2011) Antioxidative and Chemopreventive Properties of Vernonia amygdalina and Garcinia biflavonoid. Int J Environ Res Public Health 8(6): 2533-2555.

10. Adedapo AA, Olujoke JA, and Ademola AO (2014) Anti-Oxidant, Anti-Inflammatory and Antinociceptive Properties of the Acetone Leaf Extract of Vernonia Amygdalina in Some Laboratory Animals. Adv Pharm Bull 4(2): 591-598.

11. Momoh MA, Muhamed U, Agboke AA, Akpabio EI, Uduma EO (2012) Immunological effect of aqueous extract of Vernonia amygdalina and a known immune booster called immunace ${ }^{\circledR}$ and their admixtures on HIV/AIDS clients: a comparative study. Asian Pac J Trop Biomed. 2012; 2(3): 181-184.
12. Asante DB, Emmanuel EY, Precious B, Heckel AA, Elvis OA, et al. (2016) Antidiabetic Effect of Young and Old Ethanolic Leaf Extracts of Vernonia amygdalina: A Comparative Study. J Diabetes Res 8252741: 13.

13. Onasanwo SA, Oyetola TO, Abayomi MA, Mujeedat AO (2017) Anti-nociceptive and anti-inflammatory potentials of Vernonia amygdalina leaf extract via reductions of leucocyte migration and lipid peroxidation. J Intercult Ethnopharmacol 6(2): 192198.

14. Zimmermann M (1983) Ethical guidelines for investigations of experimental pain in conscious animals. Pain 16(2): 109-110.

15. Abdur R, Rehan K, Haroon K, Barkat U, Samreen P (2014) Antipyretic and antinociceptive potential of extract/fractions of Potentilla evestita and its isolated compound, acacetin. BMC Commplement Altern Med 14: 448 .

16. Muhammad N, Saeed M, Khan H (2012) Antipyretic, analgesic and anti-inflammatory activity of Viola betonicifolia whole plant. BMC Complement Altern Med 12: 59.

17. Koster R, Anderson M, De Beer EJ (1959) Acetic Acid for Analgesic Screening. Federation Proceedings 18 : 412-417.

18. Elion Itou RDG, Etou OAW, Epa C, Nsondé NGF, Bokia CB, et al. (2017) Anti-inflammatory and analgesic effects of leaves of Chromolaena odorata L. (King and Robinson). African Journal of Pharmacy and Pharmacology 11(17): 217-223.

19. Sudo RTML, Neto CES, Monteiro RV, Amaral ÂCR, Pergentino JCS, et al. (2015) Antinociceptive effects of hydroalcoholic extract from Euterpe oleracea Mart. (Açaí) in a rodent model of acute and neuropathic pain.Complement. Altern. Med 15: 208.

20. Kouakou SG, Dally I, Irie NG, Kamenan A, Kouakou L, et al. (2010) Evaluation de l'activité analgesique d'un extrait méthanolique des feuilles de mitracarpus scaber zucc. (RUBIACEAE). Santé Publique 9(2): 10.

21. Kang JY, Khan MN, Park NH, Cho JY, Lee MC, et al (2008) Antipyretic, analgesic, and anti-inflammatory activities of the seaweed Sargassum fulvellum and Sargassum thunbergii in mice. J Ethnopharmacol 116(1):187-190. 


\section{Bioequivalence \& Bioavailability International Journal}

22. Ribeiro RV, Matos da SR, Corsino da Silva JL, Tabajara de Oliveira MD (2010) Antiinflammatory, antinociceptive and antipyretic effects of hydroethanolic extract from Macrosiphonia velame (A. St.-Hil.). Pharmaceut Sci 46(3): 515-523.

23. Carolina BM, Éverton TS, Aline CQ, Daysianne PL, Morgana VA, et al. (2011) Antinociceptive and AntiInflammatory Activity from Algae of the Genus Caulerpa. Mar Drugs 9(3): 307-318.

24. Sajeli B, Bhagawati S, Goyal M, Ranjan R, Joshi VB, et al. (2010) Study of anti-inflammatory, analgesic and antipyretic activities of seeds of Hyoscyamus niger and isolation of a new coumarinolignan. Fitoterapia 81(3): 178-184.

25. Bonnard N, Brondeau MT, Jargot D, Nikolova PN, Schneider $O$ (2011) Fiche $n^{\circ} 24$ : acide acétique. In Base de données Fiches Toxicologiques. INRS.

26. Du J, Yu Y, Ke Y, Wang C, Zhu L, et al. (2007) Ligustilide attenuates pain behavior induced by acetic acid or formalin. J Ethnopharmacol 112(1): 492-496.

27. Choi EM (2007) Antinociceptive and antiinflammatory activities of pine (Pinus densiflora) pollen extract. Phytother Res 21(5): 471-475.

28. Bezera de VDI, Leite JA, Carneiro LT, Piuvezam MR., Vitorino de LMR, et al. (2011) Anti-inflammatory and Antinociceptive Activity of Ouabain in Mice. Mediators Inflamm 2011: 912-925.
29. Guirimand F (2003) Physiologie de la douleur: données récentes Version V Néphrologie 24(7): 401407.

30. Levine JD, Fields HL, Basbaum AI (1993) Peptides and the primary afferent nociceptor J Neurosci 13(6): 2273-2286.

31. Dray A (1994) Chemical activation and sensitization of nociceptors. In : BessonJM, Guilbaud G, Ollat H, eds. Peripheral neurons in nociception : Physiopharmacological aspects. Paris : John Libbey eurotext 49-70.

32. Kress M, Zeilhofer HU (1999) Capsaicin, protons and heat: New excitement about nociceptors. Trends Pharmacol Sci 20: 112-118.

33. Marnett LJ, Kalgutkar AS (1999) Cyclooxygenase 2 inhibitors: Discovery, selectivity and the future. Trends Pharmacol Sci 20(11): 465-469.

34. Mbiantcha M, Kamanyi A, Teponno RB, Tapondjou AL, Watcho P, et al. (2011) Analgesic and AntiInflammatory Properties of Extracts from the Bulbils of Dioscorea bulbifera L. var sativa (Dioscoreaceae) in Mice and Rats. Evid Based Complement Alternat Med 912935: 9.

35. Zeashana H, Amresha G, Raoa CV, Singhb S (2009) Antinociceptive activity of Amaranthus spinosus in experimental animals. J Ethnopharmacol 122(3): 492496.

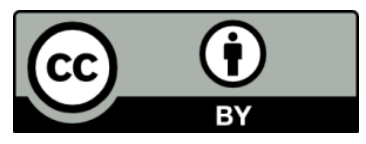

Elion Itou RDG, et al. Evaluation of Antipyretic and Analgesic Effects of Aqueous Extract of Leaves of Vernonia Amygdalina Del. (Asteraceae). Bioequiv \& Bioavailab Int J 2018, 